\title{
УДК 81’25
}

DOI https://doi.org/10.32999/ksu2663-3426/2020-2-19

\section{ЯК ПЕРЕКЛАСТИ ГОЛОВОЛОМКУ І НЕ ЗЛАМАТИ ГОЛОВУ}

\author{
Ребрій Олександр Володимирович, \\ доктор філологічних наук, професор, \\ завідувач кафедри перекладознавства імені Миколи Лукаша \\ Харківський національний університет імені В. Н. Каразіна \\ rebrii1967@gmail.com \\ orcid.org/0000-0002-4912-7489 \\ Панькова Анна Вадимівна, \\ аспірантка кафредри перекладознавства імені Миколи Лукаша \\ Харківський національний університет імені В. Н. Каразіна \\ anytka588@ukr.net \\ orcid.org/0000-0003-4495-8627
}

\begin{abstract}
Статтю присвячено висвітленню особливостей перекладацького відтворення анаграм в англо-українському художньому перекладі. Актуальність дослідження зумовлено приналежністю анаграми як різновиду мовних головоломок до глобальної категорії мовної гри, а отже й до перекладацьких труднощів, подолання яких дозволяє краще усвідомити творчий потенціал перекладу та можливості мови як системного утворення. Об'єктом дослідження виступає анаграма як фрорма мовної гри, що полягає в переставленні літер у слові / словосполученні / реченні, внаслідок чого утворюється нове слово / словосполучення / речення, що й призводить до певного стилістичного ефекту - загадкового, комічного тощо. Предметом дослідження є структурно-семантичні та комунікативно-функціональні особливості перекладу анаграми як складника художнього твору. Метою роботи є визначення оптимальних та реальних стратегій та чинників відтворення анаграм як різновиду головоломок, форми мовної гри та типу перекладацьких труднощів з англійської мови українською на основі їхніх жанрово-стилістичних, структурно-семантичних та комунікативно-функціональних параметрів. Перекладознавче опрацювання анаграми грунтується на релевантних положеннях літературознавства та мовознавства з урахуванням когнітивних та культурологічних чинників їі формування та функціонування. 3 позицій когнітивної психології дія анаграми пояснюється на основі психологічного механізму праймінгу (також «фріксування установки» або «ефекту передування»), а їі мнемонічна роль в межах художнього текстотворення визначається здатністю «схопити» та посилити фррагмент ментального або пережитого досвіду автора та вбудувати його у пам'ять читача. 3 позицій теорії перекладацьких труднощів анаграма тлумачиться як стилістичний прийом, внаслідок якого утворюється оказіональна одиниця, переклад якої ускладнюється через відсутність узуальних відповідників або неможливість їхнього використання. 3 позицій теорії мовної гри, анаграма тлумачиться як неконвенційне використання / поєднання мовних знаків, іншомовне відтворення якого вимагає від перекладача значних творчих зусиль задля збереження функціонального навантаження оригіналу. Алгоритмічний підхід до моделювання перекладу анаграми дозволяє сформулювати п'ять потенційних перекладацьких стратегій: адекватного перекладу, компенсації, фрормального перекладу, перенесення та опущення. Аналіз мовного матеріалу показав використання чотирьох із п'яти стратегій (за винятком опущення, яке, очевидно, є найрадикальнішим варіантом вирішення будь-яких перекладацьких труднощів), вибір між якими здійснюється на основі як об'єктивного (мовного), так і низки суб'єктивних (контекстно-ситуативного, нормативного, особистісного тощо) чинників.

Ключові слова: анаграма, головоломка, мовна гра, перекладацькі труднощі, стратегія.
\end{abstract}

\section{HOW TO TRANSLATE A PUZZLE AND NOT TO GET PUZZLED}

\author{
Rebrii Oleksandr Volodymyrovych, \\ Doctor of Philology, Professor, \\ Head of Mykola Lukash Translation Studies Department \\ V.N. Karazin Kharkiv National University \\ rebrii1967@gmail.com \\ orcid.org/0000-0002-4912-7489
}

Pankova Anna Vadymivna, Postgraduate Student at Mykola Lukash Translation Studies Department V. N. Karazin Kharkiv National University anytka588@ukr.net orcid.org/0000-0003-4495-8627 
The article deals with the specifics of reproducing anagrams in English-Ukrainian literary translation. The relevance of the research is determined by the reference of anagrams as a form of linguistic puzzles to the global category of language games and thus, to translation difficulties the resolution of which allows to better comprehend creative potential of translation and possibilities of language as a systemic formation. The object of research is anagram as a variety of language games that lies in rearranging letters of a word / word combination / sentence as a result of which a new word / word combination / sentence bearing a particular stylistic effect - comic, enigmatic, etc. - is formed. The subject of the research is structural, semantic and functional characteristics of translating anagrams within literary works. The aim of the research is to determine potential and real strategies as well as factors that have an impact on reproducing anagrams as a form of linguistic puzzles, variety of language games and type of translation difficulties from English into Ukrainian proceeding from their genre, stylistic, structural, semantic, functional, etc. parameters. Translatological investigation of anagrams is based on the relevant provisions of literary studies and linguistics with regard to cognitive and cultural circumstances of their formation and functioning. From the standpoint of cognitive psychology, the anagrammatic effect is explained by the mechanism of priming, and its mnemonic role within literary text is determined by the ability "to catch" and intensify the fragment of the author's mental or behavioral experience and to incorporate it into the reader's memory. From the standpoint of the theory of translation difficulties, anagram is defined as a stylistic device that leads to the formation of a nonce unit whose translation is problematized by the absence of a regular equivalent or impossibility of its use. From the standpoint of the theory of language games, anagram is defined as an unconventional use / combination of linguistic signs whose translation requires from the translator considerable creative effort for preserving functional potential of the original anagram. Algorithmic approach to modeling anagrams' translation allows to formulate five potential strategies: adequate translation, compensation, formal translation, transfer and omission. The analysis of the research material showed the use of the four out of five strategies (with exception of omission which is evidently the most radical variant of resolving any type of translation difficulties); the choice among the strategies is made on the basis of both objective (linguistic) and subjective (contextual, situational, normative, individual, etc.) factors.

Key words: anagram, language game, puzzle, strategy, translation difficulties.

1. Вступ. Головоломка є родовим поняттям, що об'єднує велику кількість онтологічно різнорідних об'єктів, в тому числі й мовних. Невипадково, що головоломка визначається у максимально загальному розумінні як «складна загадка або задача, для розв'язання якої потрібна кмітливість» (Головоломка, 1970-1980: 113). Водночас дефініції окремих різновидів головоломок часто бувають доволі розлогими, якщо в них акцентується галузь (логічні, мовні, математичні, фізичні, хімічні тощо), функція (навчальні, розважальні, розвиваючі тощо), форма, спосіб творення чи інструментарій (предметні, механічні, усні, письмові, друковані тощо), цільова аудиторія (дитячі, дорослі, жіночі, чоловічі тощо) або інші релевантні характеристики. Візьмемо для прикладу об'єкm нашого дослідження - анаграму, яка дефінується як літературний прийом /стилістична фігура (галузь), який/яка «використовується 3 метою римування чи створення різних ефектів, зокрема комічного» (функція) і полягає в «переставленні літер у слові, завдяки чому витворюється нове значення, прочитуване у зворотному напрямку» (форма/спосіб створення) (Гром'як, 2007: 35). Аналогічну ситуацію спостерігаємо, зокрема, і в англійській мові, де анаграма визначається як «форма мовної гри (галузь), в якій літери слова переставляються таким чином, аби сформувати нове слово або фразу» (форма / спосіб творення) і яка використовується «в літературі (галузь) не як безглузде розташування слів або літер», адже «має на меті пародіювання, критику або прославляння суб'єкта, позначеного вихідним словом (функція)» (Anagram) (Tym i далі переклад наш - О.Р., А.П.). Ці визначення (як і інші, подібні до них) можуть виявитися корисними при вивченні предмету нашого дослідження - особливостей перекладу анаграми, оскільки дозволяють краще уяснити три головних складника будьяких перекладацьких труднощів, які значною мірою визначають стратегію та спосіб їхнього іншомовного відтворення - форму, значення та функцію.

Таким чином, актуальність нашої розвідки зумовлено приналежністю головоломок взагалі та анаграми, зокрема, до глобальної категорії мовної гри, а отже й до перекладацьких труднощів, подолання яких в межах будь-якої мовної пари дозволяє краще усвідомити творчий потенціал перекладу та можливості мови як системного утворення.

Мета роботи полягає у визначенні оптимальних та реальних стратегій та чинників відтворення анаграм як різновиду головоломок, форми мовної гри та типу перекладацьких труднощів 3 англійської мови українською на основі виокремлення та вивчення їхніх жанрово-стилістичних, структурно-семантичних та комунікативно-функціональних параметрів.

Матеріал та методи дослідження. Анаграма, як і багато інших різновидів мовних головоломок, може розглядатися як окремий жанр (Бубнов, 2009; Anagram) або літера- 
турна/художня форма (Коновалова, 2008), тобто як самостійний текст, а може - як стилістичний прийом в межах художнього твору. Нашу увагу привертає використання анаграм в художній літературі, оскільки саме в цьому випадку вони найчастіше потрапляють у фокус уваги перекладачів, а отже й перетворюються на потенційний матеріал перекладознавчих розвідок. Анаграма як атрибут витонченої словесності зародилася в античному світі, проте пишно розквітла в європейській бароковій літературі за доби класицизму. Недарма саме ім'я найвеличнішого письменника цієї доби Вільяма Шекспіра визнають сповненою символічним змістом анаграмою: Shakespeare - shake spear («потрясати списом»). Дослідники знаходять численні анаграми в сонетах Великого Барда (Dodsworth, 2017), а в назві його знаменитої трагедії «Гамлет» насправді приховане ім'я іншого принца із середньовічної скандинавської легенди: Hamlet - Amleth. Цікаво, що в українських перекладах цю анаграму втрачено, адже Amleth транскодується українською як «Амлед». Анаграмами захоплювалися й інші англійські класики в наступні сторіччя: Джонатан Свіфт у XVIII та Льюїс Керролл у XIX. В сучасній англомовній літературі анаграми знаходимо переважно у творах пригодницького жанру, розрахованих як на дитячу (Лемоні Снікет, Джоан Ролінг), так і на дорослу (Ден Браун) аудиторію.

Методи дослідження зумовлено його комплексним характером. Так, літературознавчий аналіз дозволив виявити особливості функціонування анаграми в англомовній літературі різних історичних періодів; на основі структурно-семантичного аналізу було з'ясовано формальні та змістові характеристики анаграм; комунікативно-функціональний аналіз показав, яку роль грають анаграми у площині художнього твору; врешті-решт, порівняльний аналіз визначив, яким чином жанрово-стилістичні, структурні, семантичні та функціональні характеристики анаграм, розкриті за допомогою вказаних вище філологічних методів, визначають перекладацьку стратегію і спосіб їхнього відтворення в англо-українському напрямку перекладу.

Теоретичне обгрунтування дослідження. Науковий підхід до вивчення анаграми було започатковано батьком лінгвістичного структуралізму Фердинандом де Соссюром, який висунув доволі сміливе й неочікуване припущення про те, що анаграма лежить в основі всієї індоєвропейської поезії. Соссюр вважав анаграму не стільки художнім, скільки функціональним явищем сакральної природи, адже «підгрунтям для появи анаграм могло би бути релігійне уявлення, згідно 3 яким звернення до бога, молитва, гімн не сягають своєї мети, якщо до їхнього тексту не включено склади з імені бога» (Соссюр, 1977: 642). На думку Девіда Шепарда, Соссюрівська теорія анаграм дозволяє припустити, що, «якби можна було показати, що навіть найстаріші індоєвропейські тексти... самі $є$ продуктом анаграмічного відношення до мови, то й усі наступні літератури, що вийшли 3 цього джерела, лінгвістично та ідеологічно пов'язані в єдиній анаграмічній матриці» (Shepheard, 1982: 523). Ідеї Соссюра стали джерелом натхнення та поштовхом для вивчення інших аспектів анаграми, зокрема, філософсько-семіотичного. Так, відомий семіотик В'ячеслав Іванов, аналізуючи перехід семіотики від знака-слова до знака-тексту, піднімає проблему дискретних одиниць текстуального смислотворення, що (нерідко) залишаються неусвідомленими. «З цієї точки зору значний інтерес становить явище анаграми», завдяки якій «в ключовому слові тексту вичленовуються його складники - дискретні елементи - фонеми, до яких підбираються відповідні частини в інших словах тексту, внаслідок чого весь цей текст стягується в єдине ціле» (Иванов, 2004: 123). Геннадій Берестнєв далі розвиває цю ідею на прикладі філософського дискурсу, де анаграми утворюють «своєрідні 'точки зборки', завдяки яким [цей] дискурс отримує додаткове обгрунтування цілісності» (Берестнєв, 2014: 64).

Михайло Гронас пропонує когнітивний погляд на природу та функцію анаграми (в Соссюрівському розумінні) на основі психологічного механізму праймінгу (також «фіксування установки» або «ефекту передування») (Gronas, 2009). Одним із найбільш відомих $\epsilon$ визначення праймінгу як «зміни здатності впізнати об'єкт або вилучити з пам'яті інформацію про нього внаслідок особливої попередньої зустрічі з цим об'єктом» (Schacter, 1998). Отже, Гронас вважає, що «анаграма може насправді бути проявом перцептивного або семантичного праймінгу і через це забезпечувати мнемонічну підтримку поетичному висловленню» (Gronas, 2009: 184). Тут треба пояснити, що «під перцептивним праймінгом мають на увазі праймінг, заснований на зовнішній схожості прайма (тобто, слова-стимулу, яке активізує пам'ять - O.P., А.П.) 3 цільовим об'єктом (тобто, словом- 
результатом, яке спливає у свідомості під впливом прайма - O.P., А.П.)» (Фаликман, 2005: 95). Семантичний праймінг, натомість, «грунтується на зв'язку або схожості цих об'єктів за значенням або їхній приналежності до однієї семантичної категорії» (там само).

Таким чином, «слово, що анаграмується ('слово-тема', за термінологією Соссюра) виступає потужним праймом, який породжує хвилі активації по всіх семантичних та фонологічних мережах та робить своїх фонологічних та семантичних ‘сусідів’ більш доступними для поета в перебігу творчого процесу, тим самим допомагаючи цим словам спливти на поверхні лінгвістичної свідомості» (Gronas, 2009: 184). Якщо механізм праймінгу пояснює когнітивно-психологічну природу анаграми, її мнемонічні властивості здатні пролити світло на ту функцію, яку вона виконує в поетичному творі: подібно до рими, розміру чи алітерації, анаграма виступає потужним засобом поетичного текстотворення, здатним «схопити та посилити фрагмент ментального або пережитого досвіду поета та вбудувати його у пам'ять читача» (там само). Водночас відмінність анаграми від інших мнемонічних засобів поезії полягає в іiі неочевидності, непомітності та неусвідомленості: «Якщо анаграма $є$ наслідком семантичного та перцептивного праймінгу, варто очікувати, що вона діє в діапазоні від підсвідомого (частіше) до навмисного (рідше). Оскільки праймінг $є$ формою імпліцитної, неусвідомленої пам'яті, його ефекти не мають сягати порогу свідомості і можуть залишатися непоміченими» (там само: 191).

Хоча, як ми показали у своєму короткому огляді, анаграма виступає об'єктом численних філологічних досліджень - на перетині мовознавства, літературознавства, семіотики та когнітології, іiі перекладознавче опрацювання досі залишається в статусі terra incognita, у зв'язку з чим нам хотілося б запропонувати своє бачення вирішення проблеми іншомовного відтворення цього явища.

Варто почати з характеризації анаграми як типу перекладацьких труднощів. Для цього ми скористаємося визначенням перекладацьких труднощів як «мовних/мовленнєвих утворень різних рівнів, що спричиняють перешкоди на шляху міжмовної вербальної та невербальної взаємодії внаслідок об'єктивних розбіжностей у правилах функціонування контактуючих мов, так само як і суб'єктивного сприйняття цих розбіжностей агентом перекладацької дії, від якого вима- гаються значні творчі зусилля для їх переборення» (Ребрій, 2012: 106). Анаграма в межах художнього твору виступає стилістичним прийомом і має мовленнєву (оказіональну) природу, наслідком чого є відсутність в неї усталених відповідників в будь-якій цільовій мові. Досить важко вписати анаграму в існуючі типології перекладацьких труднощів. Наприклад, за рівневим критерієм анаграма на основі слова може бути віднесена водночас до фонетичних / фонографічних та лексичних труднощів, а за галузевим критерієм іiї атрибуція взагалі залежатиме від дослідницького ракурсу і може мати прагматичний, стилістичний, когнітивний тощо характер.

Іншим перспективним напрямком перекладознавчого опрацювання анаграми є ії приналежність до засобів мовної гри - феномену, який зазвичай тлумачиться досить вільно як «ті явища, коли мовець 'грає' з формою мовлення, коли вільне ставлення до форми мовлення отримує естетичне завдання, нехай навіть найскромніше. Це може бути і невибагливий жарт, і більш або менш вдалий дотеп, ікаламбур,ірізнівидитропів(порівняння,метафори, перифрази тощо)» (Нухов, 1997: 172). Ми не згодні $з$ тезою про те, що мовна гра має розглядатися виключно як «особливий різновид комічного», який «слугує для того, аби викликати посмішку, сміх, створити жартівливий настрій або іронічне відношення» (там само: 174).

Певніуточненнядоцьоговизначення, «вякому можна побачити елементи тавтологічності», вносить Володимир Санніков, який вказує на те, що, по-перше, мовна гра насправді $є$ мовленнєвою, адже «реалізується в мовленні з урахуванням особливостей ситуації та особливостей співбесідника», а «ефект, результат гри оказіональний, одиничний» (Санников, 2002: 15), a по-друге, намагаючись окреслити межі досліджуваного явища, «ми не гарантовані від використання текстів, автори яких, можливо, не мали на меті створення комічного ефекту» (там само). Погоджуючись 3 обома наведеними зауваженнями, зазначимо, що, на нашу думку, значно ближчим до лінгвофілософської концепції Людвіга Вітгенштейна, який і впровадив у науковий лексикон термін «мовна гра», $є$ iіi розуміння як «творчого, вільного відношення до форми мовлення, неканонічного використання мови, яке дозволяє мовцю реалізовувати здатності до мовної творчості та виділити себе як мовну особистість 3-поміж інших мовних особистостей» (Иванов, 2014: 6). Як наслідок, мовна гра дозволяє мовцю «реалізувати свої 
лінгвокреативні здібності, продемонструвати свій індивідуальний стиль» (Нухов, 1997: 137). В аспекті досліджуваної нами анаграми цікавим видається уточнення Тетяни Грідіної про те, що «мовна гра пояснюється неканонічним використанням або комбінацією мовних засобів» (Гридина, 1996: 19).

Підхід до мовної гри як творчого використання, комбінування або створення мовних знаків в перебігу вербальної комунікації розширює не тільки арсенал засобів ії реалізації, а й функціональний діапазон, до якого має бути віднесене притаманне головоломкам взагалі й анаграмі, зокрема, прагнення адресанта не тільки розважити, а й зацікавити адресанта, змусити його активізувати свій когнітивний потенціал задля ефективного вилучення прихованої інформації як стимулу для подальших дій.

Очевидно, що головним завданням перекладача при відтворенні головоломок у цільовому тексті має бути надзвичайно складне поєднання структурних, семантичних та функціональних параметрів вихідної формації, яке вимагатимете від нього значних творчих зусиль міметичного характеру: «Подібно до мистецьких об'єктів, що описуються категоріями естетики як репрезентації дійсності, ... переклади також можна представити як відображення оригіналів у цільовому культурному середовищі, створені за допомогою цільових мовних засобів на основі принципів імітаційності та імпровізаційності. Більше того, якщо ми замінимо імітаційність на звичну еквівалентність, а імпровізаційність на інтерпретацію, ми отримаємо приклад герменевтичного кола, що об'єднує лінгвістичну та культурну парадигми перекладознавства» (Rebrii, 2017: 192). Спробуємо представити можливі стратегії перекладу головоломок за допомогою популярного в (пост)радянському перекладознавстві алгоритмічного принципу, під яким розуміємо «низку дій, логічно пов'язаних, скерованих на вирішення певного завдання або класу завдань» (Ушакова, 2017: 62). Природність алгоритмічного моделювання перекладу обумовлюється його наближеністю до реального процесу формування перекладацької стратегії та прийняття в їі межах окремих рішень.

У нашому випадку алгоритм перекладу анаграми виглядає наступним чином:

- якщо структуру, семантику та функцію анаграми можна передати в перекладі, використовуючи вихідний спосіб іiі творення та словникові відповідники задіяних в оригі- налі одиниць, це забезпечить максимальний рівень адекватності. Таким чином, цей напрямок дій перекладача може бути схарактеризований як стратегія (1) адекватного перекладу;

- якщо стратегія (1) неможлива, перекладачеві необхідно модифікувати спосіб творення анаграми (якщо це можливо, залишаючись в межах цього стилістичного прийому) та/або замінити словникові відповідники задіяних в оригіналі одиниць на ситуативні (функціональні). В межах цього напрямку дій перекладача, який ми характеризуємо як стратегію (2) компенсації, функціональний параметр анаграми не зазнає змін;

- якщо стратегії (1) та (2) не можуть бути використані (через сукупність об'єктивних та суб'єктивних чинників, в тому числі й через брак перекладацької креативності) перекладач змушений залишити анаграму в цільовому тексті у іiї вихідній формі (стратегія (3) перенесення), зберегти формальні характеристики анаграми, втративши одночасно іiі семантичне та функціональне наповнення (стратегія (4) формального перекладу) або вилучити іiі взагалі (стратегія (5) опущення). Варто додати, що стратегії перенесення та формального перекладу можуть бути частково пом'якшені за рахунок додавання перекладацьких коментарів - внутрішньотекстових або позатекстових, а стратегія опущення є можливою тільки тоді, коли анаграма не має сюжетоформуючого характеру.

Практичні результати дослідження. До процесу анаграмування завжди залучено два слова, два словосполучення або два речення: вихідне, що виступає джерелом/ стимулом, та цільове, що $\epsilon$ результатом/ наслідком. В загальному сенсі складність перекладу анаграми зумовлено мовною асиметрією, адже відповідники одиниці-джерела та/або одиниці-результату можуть мати зовсім іншу літерну чи морфемну структуру в мові перекладу, що не дозволяє зберегти формальну структуру анаграми, а отже й відтворити іiі значення. Проілюструємо цю тезу на прикладі відомої анаграми з циклу романів Джоан Ролінг про Гаррі Поттера. В реченні I am Lord Voldemort (результат) авторка приховала справжнє ім'я головного антагоніста Tom Marvolo Riddle. При перекладі українською мовою Віктор Морозов був змушений вдатися до зміни одного з компонентів анаграми задля збереження тієї важливої функції ідентифікації, яку вона грала в оригіналі (стратегія компенсації). Оскільки ім'я Voldemort має 
прихований смисл (утворено від французького vol de mort, що означає flight of death - «політ смерті»), його треба було зберегти у вигляді, максимально наближеному до оригінального, а отже видозміні підлягало джерело анаграми:

He pulled Harry's wand from his pocket and began to trace it through the air, writing three shimmering words: TOM MARVOLO RIDDLE. Then he waved the wand once, and the letters of his name rearranged themselves: I AM LORD VOLDEMORT (Rowling, 1998: 231).

Він витяг з кишені чарівну паличку Гаррі i почав креслити нею в повітрі, написавши три мерехтливі слова: ТОМ ЯРВОЛОД РЕДЛ. Тоді змахнув паличкою - i літери, з яких складалося його ім'я, помінялися місиями: Я ЛОРД ВОЛДЕМОРТ (Ролінг, 2002: 318).

Можна припустити, що анаграми, до складу яких входять не тільки власні, а й загальні назви, становитимуть більше проблем для перекладача у зв'язку з тим, що останні значно рідше транскодуються, а отже можуть мати відповідники, літерний склад яких не має нічого спільного з оригінальними одиницями. Прикладом тут можуть слугувати анаграми з роману Дена Брауна "The Da Vinci Code":

Without another word, Langdon pulled a pen from his jacket pocket and rearranged the letters in each line. " $O$, Draconian devil! Oh, lame saint!" was a perfect anagram of... "Leonardo da Vinci! The Mona Lisa!” (Brown, 2004: 51).

В результаті анаграмування імені художника та назви його картини утворено кличні речення, які при перекладі українською могли би мати такий вигляд «О, драконівський дияволе!» та «О, кульгавий / скалічений / понівечений святий!». Безумовно, що кожне $з$ цих речень може бути перекладено й іншими способами, однак справедливим $є$ й припущення про те, що всі варіанти перекладу, побудовані на основі словникових відповідників, не дозволять зберегти оригінальну анаграму. Тому перекладачка твору Анжела Кам'янець робить вибір на користь стратегії перенесення, доповнюючи іiі коментарем у підрядкових виносках:

Не додавши більше ані слова, Ленгдон витягнув з кишені ручку і розташував літери в кожному рядку по-новому. O Draconian devil! Oh lame saint! Це було ідеальною анаграмою... Leonardo da Vinci! The Mona Lisa! (Браун, 2007: 69).

Повертаючись до класичних зразків анаграми, розглянемо приклад із роману-сатири Свіфта “Gulliver's travels”. У третій частині книги “A Voyage to Laputa, Balnibarbi,
Luggnagg, Glubbdubdrib and Japan” автор згадує назву королівства, яке колись відвідав протагоніст-мандрівник:

I told him, "that in the kingdom of Tribnia, by the natives called Langden, where I had sojourned some time in my travels, the bulk of the people consist in a manner wholly of discoverers, witnesses, informers, accusers, prosecutors, evidences, swearers..." (Swift).

Вигадана країна, про мешканців якої герой не надто високої думки, є насправді зашифрованою в анаграмі назвою батьківщини Свіфта $($ Tribnia $=$ Britain, Langden $=$ England $)$, що дає нам можливість виокремити ще одну функцію анаграми - ідеологічну, адже саме таким чином письменник намагався приховати своє критичне ставлення до політичної ситуації у Великобританії. В українському перекладі Миколи Іванова, виконаному ще у 30 -ті роки минулого сторіччя, застосовано стратегію формального перекладу, а фактичну втрату анаграми дещо компенсує доданий редактором коментар:

Я сказав йому, що в королівстві Трібнія, яке тамтешній народ називає Лангден, там я жив під час однієї подорожі, - головна маса населення складається з викажчиків, свідків, інформаторів, обвинувачів, позивачів, очевидиів, присяжних... (Свіфт, 2009: 242).

Уникаючи зайвої прескриптивності, все ж таки зазначимо, що в цьому випадку адекватне відтворення анаграми (стратегія 1) не становить жодних труднощів, наприклад: Британія = Трибнія, Англія = Лангія. Натомість, ще один цікавий випадок анаграмування не має такого легкого вирішення. Йдеться про назву заселеної велетнями території на півночі американського континенту - Brobdingnag, яка, як припускається, утворена за рахунок перемішування літер 3 трьох англійських слів: big, grand та noble. Можливість збереження анаграми в українському перекладі зводиться нанівець завдяки двом чинникам: в іiі основі лежить не один власний іменник, а цілих три загальних прикметники. Тож цілком закономірно назва транслітерується як «Бробдінгнег» (стратегія формального перекладу), а анаграма втрачається.

Завершаючи свій огляд, наведемо приклад множинних перекладів анаграми 3 казки Льюїса Керролла "Alice's adventures in Wonderland”. Наявність декількох варіантів перекладу одного твору, до того ж виконаних у різні періоди, дозволяє, по-перше, порівняти стратегії окремих перекладачів та оцінити рівень їхньої креативності, а по-друге, 
пересвідчитися, які погляди на відтворення того чи іншого типу перекладацьких труднощів панували в певний історичний період.

Як відомо, Керролл захоплювався різними мовними головоломками, які стали провідною ознакою його індивідуального стилю. Не оминув він своєю увагою й анаграми. Зокрема, в розділі першої книги про Алісу "A mad tea-party" зустрічаємо таку ситуацію:

"Once upon a time there were three little sisters," the Dormouse began in a great hurry; "and their names were Elsie, Lacie, and Tilly; and they lived at the bottom of a well -" (Carroll, 1998 : 100).

За іменами казкових персонажів Керролл приховав справжні імена сестер Лідделл. I якщо Tilly є звичним скороченням від Matilda - прізвиська молодшої сестри Едіт, то два інших імені $є$ анаграмами: Elsie становить собою транскрипцію ініціалів старшої сестри Лоріни Шарлоти (L.C. = Lorina Charlotte), a Lacie позначає саму Алicy $($ Lacie $=$ Alice $)$.

Перший переклад у нашому списку належить Галині Бушиній і датований 1960 роком:

- Були собі три сестрички, - швиденько почав Вовчок, - $і$ звали їх Ельзі, Лейсі та Тіллі. А жили вони на дні колодязя (Керрол, 1960: 70).

Перекладачка передає імена за допомогою транскодування, тим самим обираючи стратегію формального перекладу і втрачаючи анаграму для цільового читача.

Наступним іде переклад, виконаний через сорок років після першого Віктором Корнієнком на замовлення видавництва «А-БА-БАГА-ЛА-МА-ГА»:

- Колись давно жили собі три сестрички, швидко заторохтів Сонько, - $i$ звали їх Олша, Асіла $i$ Тільда. I жили вони на дні криниці (Керрол, 2001: 72).

Для першого імені перекладач обирає стратегію компенсації, адже Олша, очевидно, $\epsilon$ модифікованою транскрипцією ініціалів Лорини Шарлоти: Олша = ОлШа = ЛоШа. Можемо припустити, що Корнієнко обрав саме такий варіант через евфонічні міркування, аби уникнути небажаного співзвуччя імені персонажа з лошаком. Для другого імені перекладач обирає стратегію адекватного перекладу: Асіла = Аліса.

Останнім в нашому переліку $є$ переклад Вікторії Наріжної для харківського видавництва «Фоліо», вперше надрукований у 2008 році:

- Давним-давно жили собі три маленькі сестрички, - швидко заторохтів Соня, а звали їх Елсі, Лейсі та Тіллі, і мешкали вони на дні криниці... (Керрол, 2008: 75)
Незважаючи на певні відмінності в перенесенні імен 3 латиниці кирилицею (Ельзі vs Елсі), переклад Наріжної реалізує ту ж саму формальну стратегію, що й переклад Бушиної. Втім, аби принаймні частково компенсувати втрату анаграми, перекладачка додає роз'яснювальний коментар.

Висновки. Проаналізувавши літературознавчий та мовознавчий аспекти анаграми, ми отримали міцне філологічне підгрунтя для подальшого їі вивчення в межах різних перекладознавчих підходів. Зокрема, у світлі теорії перекладацьких труднощів анаграма розглядається як стилістичний прийом, внаслідок якого утворюється оказіональна одиниця, переклад якої ускладнюється через відсутність узуальних відповідників або неможливість їхнього використання. 3 позицій мовної гри, анаграма є складним випадком неконвенційного поєднання мовних знаків, іншомовне відтворення якого вимагає від перекладача значних творчих зусиль задля збереження структурних, семантичних та функціональних параметрів оригіналу. Моделювання перекладу анаграми на основі алгоритмічного принципу дозволяє виокремити п'ять потенційних перекладацьких стратегій: адекватного перекладу, компенсації, формального перекладу, перенесення та опущення. Аналіз мовного матеріалу показав використання чотирьох із п'яти стратегій (за винятком опущення, яке, очевидно, є найрадикальнішим варіантом вирішення будь-яких перекладацьких труднощів), вибір між якими здійснюється на основі як об'єктивного (мовного), так і низки суб'єктивних (контекстно-ситуативного, нормативного, особистісного тощо) чинників.

Перспективою подальших розвідок в обраному напрямку $\epsilon$ вивчення особливостей англо-українського відтворення інших різновидів мовних головоломок.

\section{ЛІТЕРАТУРА:}

1. Берестенев Г.И. Философрские аспекты анаграмм. Вестник Балтийского федерального университета им. И. Канта. 2014. Вып. 6. С. 63-71.

2. Бубнов А. Преломление слова как хлеба, или буквологика Анны Ковальчук (ингредиенты к «словареву»). Детu Ра. 2009. № 11 (61). URL: http://reading-hall.ru/ publication.php?id=1248 (дата обращения: 10.08.2020).

3. Головоломка. Словник української мови: в 11 тт. АН УРСР. Інститут мовознавства / за ред. І. К. Білодіда. Київ : Наукова думка, 1970-1980. Т. 2. С. 113.

4. Гридина Т.А. Ассоциативный потенциал слова и его реализация в речи. Явление языковой игры: 
дис. ...д-ра фрилол. наук : 10.02.01 - Русский язык. Москва, 1996. 566 с.

5. Гром'як Р.Т., Ковалів Ю.І., Теремко В.І. Анаграма. Літературознавчий словник-довідник. Київ : ВЦ «Академія», 2007. С. 35.

6. Дементьев И.О. Старая «новая мания»: анаграммы в западной политической традиции. Ретроспектива: Всемирная история глазами молодых исследователей. 2014. С. 98-111.

7. Иванов В.В. Избранные труды по семиотике и истории культуры. Т. 3. Москва, 2004. Сравнительное литературоведение. Всемирная литература. Стиховедение. 815 с

8. Коновалова Ю.О. Языковая игра в современной русской разговорной речи. Владивосток : ВГУЭС, 2008. 196 с.

9. Нухов С.Ж. Языковая игра в словообразовании. На материале лексики английского языка: дис. ... д-ра фрилол. наук : 10.02.04 - Германские языки. Москва, 1997. 372 c.

10. Ребрій О. В. Сучасні концепції творчості у перекладі монографія. Харків : ХНУ імені В. Н. Каразіна, 2012. $376 \mathrm{c}$.

11. Русская разговорная речь. Фонетика. Морфология. Лексика. Жест / за ред. Е.А. Земской. Москва : Наука, 1983. $239 \mathrm{c}$.

12. Санников В.3. Русский язык в зеркале языковой игры. 2-е изд., испр. и доп. Москва : Языки славянской культуры, 2002. 552 с.

13. Соссюр Ф. Отрывки из тетрадей Ф. де Соссюра, содержащих записи об анаграммах. Труды по языкознанию : пер. с франц. яз. под ред. А. А. Холодовича / ред. М. А. Оборина; предисл. проф. Н.С. Чемоданова. Москва : Прогресс, 1977. 696 с.

14. Ушакова А.О. Алгоритмические и эвристические механизмы мышления переводчика-лингвиста. Вестник ПНИПУ. Проблемы языкознания и педагогики. 2017. № 1. С. 60-67.

15. Фаликман М.В., Койфман А.Я. Виды прайминга в исследованиях восприятия и перцептивного внимания. Вестник Московского университета. Серия 14. Психология. Москва 2005. № 3. С. 86-97.

16. Anagram. Literary Devices. Definition and Examples of Literary Terms. URL: https://literarydevices.net/anagram (Last accessed: 10.08.2020).

17. Dodsworth M. The Elizabethan anagram and Shakespeare's sonnets. The Review of English Studies. 2017. № 68(286). P. 666-688.

18. Gronas M. Just What Word Did Mandel'shtam Forget? A Mnemopoetic Solution to the Problem of Saussure's Anagrams. Poetics Today. 2009. № 30 (2). P. 155-205.

19. Rebrii O. Translation as an Art: A Mimetic Background. Language - Literature - the Arts: A Cognitive-Semiotic Interface. Text - Meaning - Context. Frankfurt am Main : Peter Lang, 2017. Vol. 14. P. 183-196.

20. Schacter D.L., Buckner R.L. Priming and the brain. Review. Neuron. 1998. Vol. 20. Issue 2. P. 185-195.

21. Shepheard D. Saussure's Vedic anagrams. Modern Language. 1982. Vol. 2, № 3. P. 513-523.

\section{СПИСОК ДЖЕРЕЛ ФАКТИЧНОГО МАТЕРІАЛУ:}

1. Браун Д. Код да Вінчі : пер. з англ. А. Кам'янець. Харків : Книжковий Клуб "Клуб Сімейного Дозвілля", 2007. 480 c
2. Керрол Л. Аліса в Дивокраї : пер. з англ. В. Г. Наріжної / іл. Є. Г. Гапчинської; худож.-офрормлювач С. І. Правдюк. Харків : Фоліо, 2008. 139 с.

3. Керрол Л. Аліса в Країні Чудес; Аліса в Задзеркаллі : пер. з англ. В. Корнієнко; за ред. І. Малковича та Ю. Андруховича. Київ : А-БА-БА-ГА-ЛА-МА-ГА, 2001. 262 c.

4. Керрол Л. Аліса в країні чудес : пер. з англ. Г. Бушиної. Київ : Радянський письменник, 1960. 247 с.

5. Ролінг Дж. Гаррі Поттер і таємна кімната : пер. з англ. Віктора Морозова. Київ : А-БА-БА-ГА-ЛА-МА-ГА, 2002. 352c.

6. Свіфт Дж. Мандри Ґуллівера : пер. з англ. М. Іванова за ред. Р. Доценка. Київ : А-БА-БА-ГА-ЛА-МА-ГА, 2009. 384 с.

7. Brown D. The Da Vinci Code. London : Corgi, 2004. 592 p.

8. Carroll L. The Annotated Alice: Alice's Adventures in Wonderland and Through the Looking Glass / Introduction and Notes by M. Gardner. New York : Wings Books, 1998. $352 \mathrm{p}$.

9. Rowling J.K. Harry Potter and the Chamber of Secrets. London : Bloomsbury, 1998. 251 p.

10. Swift J. Gulliver's Travels. URL: http://www.onlineliterature.com/swift/gulliver/ (Last accessed: 10.08.2020)

\section{REFERENCES:}

1. Berestenev, G.I. (2014). Filosofskie aspekty anagramm. Vestnik Baltijskogo federal'nogo universiteta im. I. Kanta [Philosophical aspects of anagrams. Bulletin of Immanuel Kant Baltic Federal University]. Vyp. 6. S. 63-71 [in Russian].

2. Bubnov, A. (2009). Prelomlenie slova kak hleba, ili bukvologika Anny Koval'chuk (ingredienty k «slovarevu») [The refraction of a word like bread, or Anna Kovalchuk's literal logic (ingredients for the "dictionary")] Deti Ra. № 11 (61). Retrieved from: http://reading-hall.ru/ publication.php?id=1248 [in Russian].

3. Golovolomka. Slovnik ukrai'ns'koi' movi (1970-1980) [Puzzle. Dictionary of the Ukrainian language]: v $11 \mathrm{tt}$. I AN URSR. Institut movoznavstva; / za red. I. K. Bilodida. Kii'v: Naukova dumka, T. 2. S. 113 [in Ukrainian].

4. Gridina, T.A. (1996). Associativnyj potencial slova i ego realizacija $v$ rechi. Javlenie jazykovoj igry [The associative potential of a word and its implementation in speech. The phenomenon of the language game]: dis. ...d-ra filol. nauk: Moskva, 566 s. [in Russian].

5. Grom'jak, R.T., Kovaliv Ju.I., \& Teremk V.I. (2007). Anagrama. Literaturoznavchyj slovnyk-dovidnyk [Anagram. Literary dictionary-reference book]. Kyi'v: VC «Akademija», S. 35. [in Ukrainian].

6. Dement'ev, I.O. (2014). Staraja «novaja manija»: anagrammy $v$ zapadnoj politicheskoj tradicii. Retrospektiva: Vsemirnaja istorija glazami molodyh issledovatelej [The Old New Mania: Anagrams in Western Political Tradition. Retrospective: World history through the eyes of young researchers]. S. 98-111. [in Russian].

7. Ivanov, V.V. (2004). Izbrannye trudy po semiotike i istorii kul'tury [Selected works on semiotics and cultural history]. T. 3. Moskva, 2004. Sravnitel'noe literaturovedenie. Vsemirnaja literatura. Stihovedenie, 815 s. [in Russian].

8. Konovalova, Ju.O. (2008). Jazykovaja igra v sovremennoj russkoj razgovornoj rechi [Language game in modern 
Russian colloquial speech]. Vladivostok: Izd-vo VGUJeS, 196 s. [in Russian].

9. Nuhov, S.Zh. (1997) Jazykovaja igra v slovoobrazovanii. $\mathrm{Na}$ materiale leksiki anglijskogo jazyka [Language game in word formation. Based on the vocabulary of the English language]: dis. ...d-ra filol. nauk. Moskva, 372 s. [in Russian].

10. Rebrij, O.V. (2012). Suchasni koncepcii' tvorchosti u perekladi [Modern concepts of creativity in translation]: monografija. Harkiv: HNU imeni V. N. Karazina, 376 c. [in Ukrainian].

11. Russkaja razgovornaja rech'. Fonetika. Morfologija. Leksika. Zhest (1983) [Russian colloquial speech. Phonetics. Morphology. Vocabulary. Gesture] /za red. E.A. Zemskoj. Moskva: Nauka, 239 s. [in Russian].

12. Sannikov, V.Z. (2002). Russkij jazyk v zerkale jazykovoj igry [Russian language in the mirror of a language game]. 2-e izd., ispr. i dop. Moskva: Jazyki slavjanskoj kul'tury, $552 \mathrm{~s}$. [in Russian].

13. Sossjur, F. (1977). Otryvki iz tetradej F. de Sossjura, soderzhashhih zapisi ob anagrammah. Trudy po jazykoznaniju [Fragments from F. de Saussure's notebooks containing notes on anagrams. Works on linguistics]. /per. s franc. jaz. pod red. A. A. Holodovicha; red. M. A. Oborina; predisl. prof. N.S. Chemodanova. Moskva: Progress, $696 \mathrm{~s}$. [in Russian].

14. Ushakova, A.O. (2017). Algoritmicheskie i jevristicheskie mehanizmy myshlenija perevodchika-lingvista [Algorithmic and heuristic thinking mechanisms of a translator-linguist.]. Vestnik PNIPU. Problemy jazykoznanija i pedagogiki. № 1, S. 60-67 [in Russian].

15. Falikman M.V., \& Kojfman A.Ja. (2005). Vidy prajminga $\mathrm{v}$ issledovanijah vosprijatija i perceptivnogo vnimanija [Types of priming in studies of perception and perceptual attention]. Vestnik Moskovskogo universiteta. Serija 14. Psihologija. Moskva, № 3. S. 86-97. [in Russian].

16. Anagram. Literary Devices. Definition and Examples of Literary Terms. Retrieved from: https://literarydevices.net/ anagram [in English].

17. Dodsworth, M. (2017). The Elizabethan anagram and Shakespeare's sonnets. The Review of English Studies. № 68(286). P. 666-688. [in English].

18. Gronas, M. (2009). Just What Word Did Mandel'shtam Forget? A Mnemopoetic Solution to the Problem of
Saussure's Anagrams. Poetics Today, 30 (2). P. 155-205. [in English].

19. Rebrii, O. (2017). Translation as an Art: A Mimetic Background. Language - Literature - the Arts: A CognitiveSemiotic Interface. Text-Meaning - Context. Frankfurt am Main: Peter Lang, Vol. 14. P. 183-196. [in English].

20. Schacter, D.L., \& Buckner, R.L. (1998). Priming and the brain. Review. Neuron, Vol. 20. Issue 2. P. 185-195. [in English].

21. Shepheard, D. (1982). Saussure's Vedic anagrams. Modern Language. Vol. 2, № 3. P. 513-523. [in English].

\section{ACTUAL MATERIAL:}

22. Braun, D. (2007). Kod da Vinchi [The Da Vinci Code] / per. z angl. A. Kam'janec'. Harkiv: Knyzhkovyj Klub "Klub Simejnogo Dozvillja", 480 s. [in Ukrainian].

23. Kerrol, L. (2008). Alisa v Dyvokrai' [Alice in the Wonderland]. / per. z angl. V. G. Narizhnoi'; il. Je. G. Gapchyns'koi'; hudozh.-oformljuvach S.I. Pravdjuk. Harkiv: Folio, 139 s. [in Ukrainian].

24. Kerrol, L. (2001). Alisa v Krai'ni Chudes; Alisa v Zadzerkalli. [Annotated Alice: Aloce's Adventures in Wonderland and Through the Looking Glass]/ per. z angl. V. Kornijenko; za red. I. Malkovycha ta Ju. Andruhovycha. Kyi'v: A-BA-BAGA-LA-MA-GA, 262 s. [in Ukrainian].

25. Kerrol, L. (1960). Alisa v krai'ni chudes [Alice in the Wonderland] / per. z angl. G. Bushynoi'. Kyi'v: Radjans'kyj pys'mennyk, $247 \mathrm{~s}$. [in Ukrainian].

26. Roling, Dzh. (2002). Garri Potter i tajemna kimntata[Harry Potter and the Chamber of Secrets]. / per. $z$ angl. Viktora Morozova. Kyi'v: A-BA-BA-GA-LA-MA-GA, 352 s. [in Ukrainian].

27. Svift, Dzh. (2009). Mandry G'ullivera [Gulliver's Travels]. I per. $z$ angl. M. Ivanova za red. R. Docenka. Kyi'v: A-BABA-GA-LA-MA-GA, 2009. 384 s. [in Ukrainain].

28. Brown, D. (2004). The Da Vinci Code. London: Corgi, 592 p. [in English].

29. Carroll, L. (1998). The Annotated Alice: Aloce's Adventures in Wonderland and Through the Looking Glass I Introduction and Notes by M. Gardner. New York: Wings Books, 352 p. [in English].

30. Rowling, J.K. (1998). Harry Potter and the Chamber of Secrets. London: Bloomsbury, 251 p. [in English].

31. Swift, J. Gulliver's Travels. Retrieved from: http://www. online-literature.com/swift/gulliver/ [in English].

Стаття надійшла до редакиії 27.10.2020. The article was received October 27, 2020. 